\title{
FROM THE EDITORIAL BOARD
}

\section{LEGENDS OF PLACES AS PART OF THE SUSTAINABLE DEVELOPMENT OF REGIONS}

\author{
Barbara Ivančič Kutin \\ Institute of Slovenian Ethnology \\ Research Centre of the Slovenian Academy of Sciences and Arts \\ Ljubljana, Slovenia \\ B.Ivancic@zrc-sazu.si
}

\author{
Monika Kropej Telban \\ Institute of Slovenian Ethnology \\ Research Centre of the Slovenian Academy of Sciences and Arts \\ Ljubljana, Slovenia \\ monika@zrc-sazu.si
}

\begin{abstract}
Many newly established thematic routes and parks include narrative traditions to be experienced in their natural environment. Quality products of this kind are the result of well-developed concepts that follow expert guidelines and strategies and can be, as such, part of sustainable tourism, which strives to preserve ties with tradition to the greatest extent possible. This article includes some examples of different presentations of narrative tradition or local legends in places and discusses the problems with which such presentations cope. The article particularly discusses two examples of thematic trails that are based on professional folklore and ethnological research. The first case involves research activities that served as the foundation for thematic storytelling routes in the eastern part of the Alps - Pohorje above Slovenska Bistrica in Slovenia - and in central Istria in Croatia. The second example shows the influence of a thematic trail on the knowledge about local narrative tradition among schoolchildren in Bovec in the north-western part of Slovenia.
\end{abstract}

Keywords: cultural heritage, education, folklore, folktale trails, local legends, narrative culture, sustainable tourism

\section{INTRODUCTION}

Research into local narrative tradition connected with places in cultural landscapes is becoming an increasingly discussed subject in contemporary folklore studies. It is often used for the sustainable development of regions and for the enhancement of social, cultural, and economic situations. Narrative tradition 
plays a vital role in preserving the identity and culture of local social communities; it increases the cultural level of the inhabitants and improves their quality of life (Mathisen 1993). Narrative tradition can also serve as a basis for various activities aimed at raising awareness and the preservation of the cultural identity of existing communities in a given local environment. At the same time - if it is well transmitted - it can also improve their cultural and economic standards. Folktales and legends of communities contain a great deal of information on the living conditions, beliefs, and world views of the people from the times in which these narratives came to be and were passed on; therefore, they can also be considered to be social and performative acts in time and space (e.g. Bird 2002; Cashman 2011 [2008]).

Folklore contents have a wider reach than it appears at first sight, because oral narrative patterns can survive in many ways: in fragments, in whole, or in completely new forms. They can be found in different contexts, and transmitted through different forms or genres of folklore (a story can become a saying, proverb, local phrase, etc.); they intermingle with literature and other forms of art and can be encountered in tourist and commercial services, as well as in the advertising industry. Traditional forms and contents of storytelling adapt to cultural and social changes; thus, new forms and genres arise, which are subjected to new means of transmission, and they consequently undertake new functions and roles (Kropej 2007; Ivančič Kutin 2017). Therefore, changes in oral folklore take place both at the diachronic and synchronic levels, because changes are strongly influenced by space and time, and the social environment in which folklore resides, as well as by the means or medium of transmission.

Traditional narrative genres and contents no longer depend solely on oral transmission; they can be recorded in graphic, audio, or video form; the audience can be reached through print, television, the internet, and social networks, which consequently alters their basic function. All this brings forth perfectly new forms of narrative culture, related to new means of transmission, which in turn allows for the internationalization and globalization of folklore. In this context, new research approaches and methods must be and are being implemented, as well as new guidelines and strategies for the preservation and dissemination of narrative cultural heritage.

Places obtain their meanings through cultural and historical dimensions, personal experiences, and local narratives. They store collective memories of the mythic past. Since the 1990s, researchers have become ever more interested in studying narratives connected with places. At that time a new concept emerged in Estonian folklore studies - kohapärimus (place-lore), which soon became a distinct field of study, the importance of which has only increased in the following years (Valk \& Sävborg 2018: 9). The concept of place-lore has close 
affinities with the notion of narratives in the environment, and transmits the web of meanings that come into being through the interaction between mobile humans and rural and urban landscapes (Valk \& Sävborg 2018: 10).

Researchers' strategies for the preservation of local narrative tradition or intangible cultural heritage include documenting, keeping records, and studying. This type of research work is often included in projects with the aim of supporting the transmission and maintenance of local tradition in its original environment. Preservations and presentations require effective strategies based on the research that offers an overview of the sources, from the oldest to the most recent ones. This enables us to keep a record of the contents and changes in narrative culture over the course of time in relation to the motifs, genres, storytellers, and the past and present role of storytelling within a certain social group and region.

The research studies in question show that folklore not only reflects social changes but also successfully responds and adapts to them. However, the adaptation does not occur merely as a result of social and technological changes, but also due to the function or purpose of the presentations. This inevitably brings us to the following question: To what extent is folklore still folklore?

Many folklore studies have addressed this issue (Moser 1962; Köstlin 1970; Bausinger 1969; Bošković-Stulli 1971; Rihtman Auguštin 1978; etc.). Hans Moser introduced the term "folklorism" (folklorismus), which he used to describe as the second-hand presentation of culture. He identified three types of folklorism: the performance of traditionally and functionally determined elements of folk culture outside that culture's local or class community; playful imitations of folk motifs in another social stratum; and the purposeful invention and creation of "folklike" elements outside any tradition (Moser 1962: 190). According to his historical orientation, he also distinguished between folklorism of the past, which sought to represent the soul of the folk, and the folklorism of our time which is primarily commercially determined and deeply anchored in the tourism and entertainment industry (Bendix 1997: 176-178).

Due to the understanding of folklore as a static phenomenon, some authors began to distinguish between "true, authentic" and "false, factitious" folklore, so in Europe folklorism, therefore as "false" folklore, has an almost exclusively negative connotation. In the USA, however, the notion of "fakelore" was established (Klaus 2014: 32, 33). However, as early as in the 1970s, Maja BoškovićStulli pointed out that the folklorist's job is to attempt to understand and not to deprecate the phenomenon of folklorism (Bošković-Stulli 1971: 184-185). Dunja Rihtman Auguštin has stated that it is possible to retain a distinction between folklore and folklorism (as degraded folklore) with the focus on the process between two opposing poles rather than theoretical poles themselves (Rihtman Auguštin 1978). 
The debate on folklorism in relation to folklore among folklorists has continued (e.g. Bendix 1997; Šmidchens 1999; Poljak Istenič 2011; March 2013; Klaus 2014). Most authors believe that the dividing line between folklore and folklorism is very blurred. Moreover, in a way, folklore and folklorism are one and the same or, if we can separate them at all, are strongly intertwined (Klaus 2014: 32).

We have to consider the dynamic dimension of folklore, which also includes folklorismus especially in connection with the preservation of intangible cultural heritage. In order to ensure the preservation of cultural identity in a specific environment, we have to think of ways that strongly connect it to tradition, while simultaneously ensuring the enhancement of the cultural level and quality of life.

Live storytelling, which we no longer have a chance to hear in private settings and as part of everyday life, is moving to the public space in the form of storytelling events, festivals, and folktale trails. Such events and performances are often contextually well developed and can follow the aim of preservation and dissemination of oral folklore among the target audience (local and interest groups). Certain storytelling festivals and events function by carefully selecting their repertoire, mostly from national or local narrative traditions (Ivančič Kutin 2010; Frlic 2016). In Slovenia, the most recognized festival of this kind is the storytelling festival Pravljice danes (Stories Today) in Ljubljana (Source 4). In contrast, these aims can be pursued by preparing well-thought-out thematic trails based on narrative folklore, which can be even more effective, since they can be experienced in their natural environment.

\section{DIFFERENT CONCEPTS OF FOLKTALE TRAILS AND PRESENTATIONS OF LOCAL LEGENDS IN PLACES}

Oral history is a social process that is, among other things, incorporated into the dynamics of the learning process and historical beliefs. Folklorists explore and analyse various impacts on narrative culture and its development. Regina Bendix has noted that tourism relies to a great extent on narration and narrative potential aiming to attract travellers who wish to learn something new and genuine about the sights (Bendix 2002: 473). Legends have served to preserve the knowledge of these places as well as the beliefs connected with them, even up to the present day (Valk \& Sävborg 2018: 11). Contemporary researchers of narrative culture often focus on the role of the reconstructed narrative tradition in cultural and tourist services (Chittenden 2011; Goldstein \& Gryder \& Banks Thomas 2007); on folklore and storytelling events (Pöge-Alder 2010), and on 
the revival of folktales in the press, on stages on the internet, and other media (Krawczyk-Wasilewska \& Meder \& Ross 2012; Kõiva 2009).

Many researchers (e.g. Chittenden 2011) note that the presentation of the narrative heritage of places by means of oral performance has a significant impact on sightseeing tours, and cultural and educational activities, since it helps the visitors and the audience to imagine the lifestyles of the past and the events of a particular area more easily, and to remember the traditions more vividly.

A so-called site of memory attracts people's attention more strongly: it enables them to memorize the message easily, while simultaneously encouraging them to become immersed into the story and space.

In Europe and the rest of the world, folktale trails and parks started to appear mostly in the second half of the twentieth century, but they vary in concepts and quality. The quality of these products - the level of their relation to the tradition and contribution to the preservation of the local/national identity - mostly depends on the level of the expert basis on which these products are founded, on the selection of material: folktales and their presentation. The purpose of these products is to offer the visitors a memorable experience, which helps them to remember the sights and narratives more vividly.

Until now different types of folktale trails have been developed, following various praxes and methods, such as:

1. information boards on which the narratives are presented;

2. tourist guides or teachers telling narratives along the trails;

3. brochures or booklets leading the way;

4. digital guides or applications guiding the route;

5. audio recordings of folktales on audio guides inserted throughout the locations;

6. sculptures or pictures which reveal the stories marking the places;

7. different events or performances taking place in certain locations in natural environments.

\section{SOME EXAMPLES OF LEGEND TRIPPING}

For over half a century, storytelling has been supported by the Scottish Storytelling Centre in Edinburgh (Source 1), which organizes many events, among them the Scottish International Storytelling Festival, with numerous accompanying events. The city's permanent tourist services present an array of themed trails. Folklore storytellers or even professional storytellers guide the visitors through various scenes related to the chosen trail (historic buildings, streets, parks, and also cemeteries, underground tunnels, and other scenes, which are out of reach 
for an average tourist without the help of a guide) while narrating stories (educational, scary, humorous, etc.). The guides perform so-called legend tripping (Ellis 1996), and this praxis has become very popular in Western countries.

Estonia is also rich in thematic trails; the city of Pärnu, for example, offers a fairy-tale trail for children in the Lottemaa theme park (Source 2).

A good example of literary trails is the engaging trail around the Malbork Castle in Poland (Stokowski 2013), or the literary trail of Ljubljana based on anecdotes and other stories about the life and work of famous Slovenian writers: the Literary Atlas of Ljubljana (Dolgan \& Fridl \& Volk 2014), to name but two.

In the Austrian part of Carinthia, the cultural landscape is documented with folktales, which are often presented with images. They are inserted from the Tscheppaschlucht Waterfalls in Kärnten to Windisch Bleiberg above the Loibl Pass to Bodental, with the magical meadow Märchenwiese and a little round Lake Meerauge, which is a popular tourist attraction (Kropej 2003; Source 5).

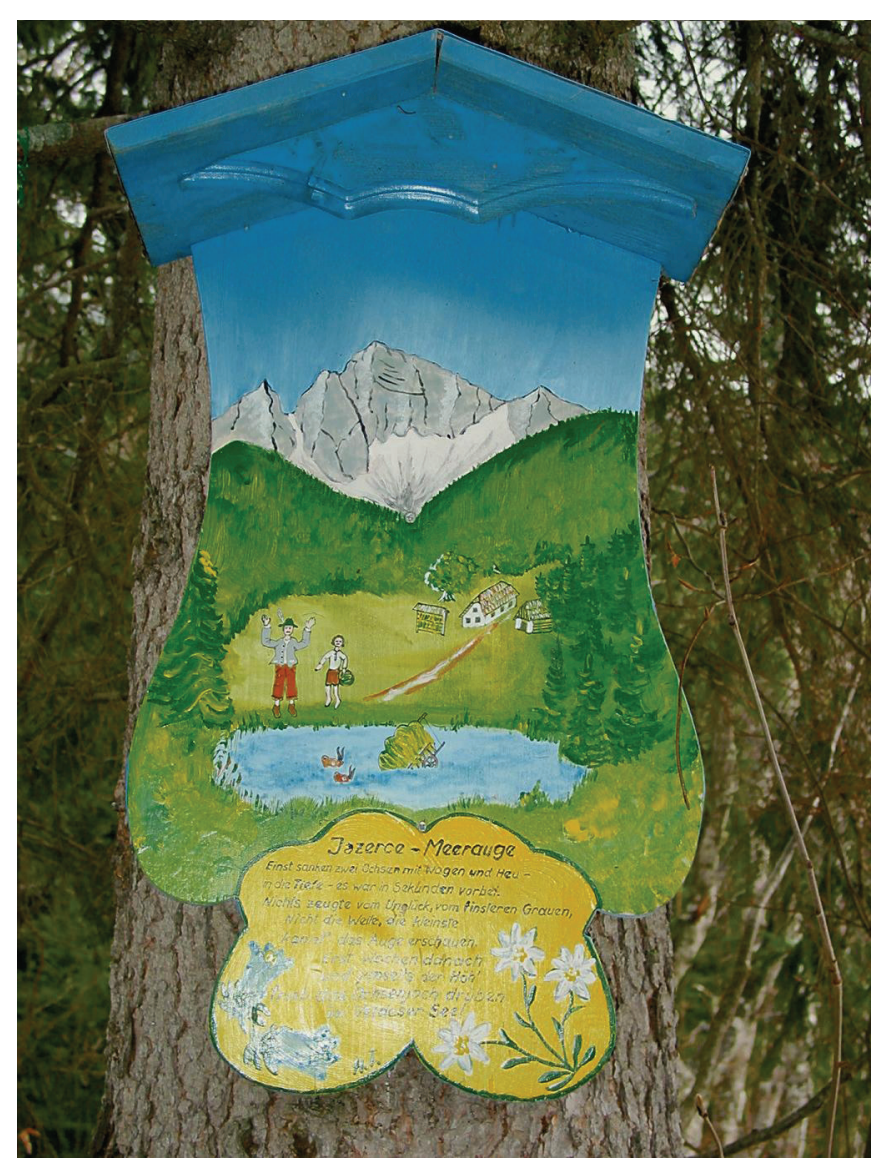




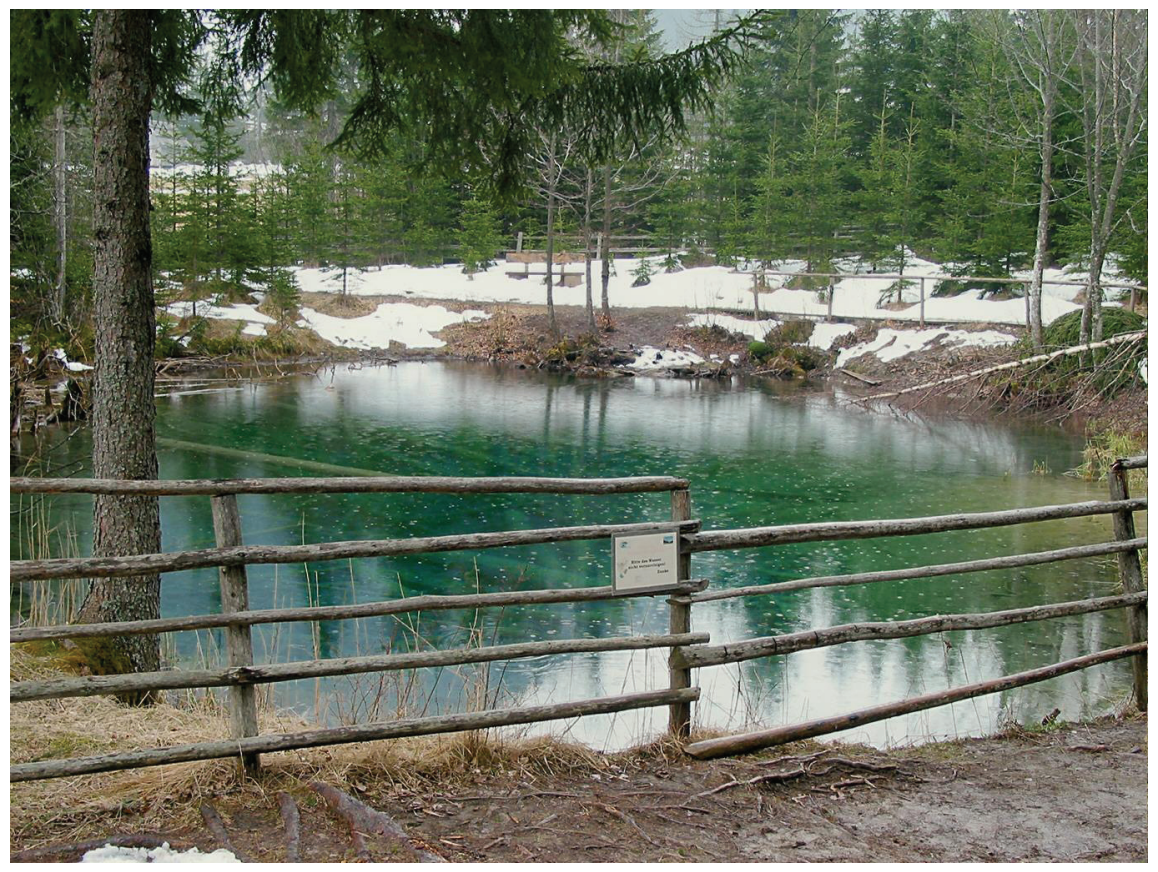

Figure 1a, 1b. Meerauge trail in Bodental above the Loibl Pass in Austria. Photograph by Monika Kropej 2003.

\section{Slovenian examples}

One of Slovenia's first fairy-tale parks is Koča pri čarounici (The Witch's Hut) in Olimje (Source 3; Ivančič Kutin \& Marjanić 2015), established by Jože Brilej in 1993.

At the beginning of the twenty-first century, these kinds of products became more numerous. In 2006, the fairy-tale trail in the Alpine area of Mount Triglav, Rajže po poteh triglavskih pravljic (Along the paths of Triglav fairy tales), was opened in Dovje near Mojstrana (Source 10). It was based on folktales published by Mirko Kunčič (Lesce 1899 - Buenos Aires 1984), who was a Slovenian children's author and poet. His collections of folktales (Kunčič 1940, 1944) were very popular.

Another folktale trail was designed in Kamnik and Motnik by Irena Cerar, who has also written a folktale guide (Cerar 2015) and sometimes leads visitors through the trail by narrating stories. She has also prepared other folktale trails, for example, Zlatorogova pravljična pot (Goldenhorn's fairy-tale trail) in Bohinj (Source 6), and is the author of the guidebook Pravljične poti Slovenije (Folktale routes of Slovenia) (Cerar Drašler 2004). 


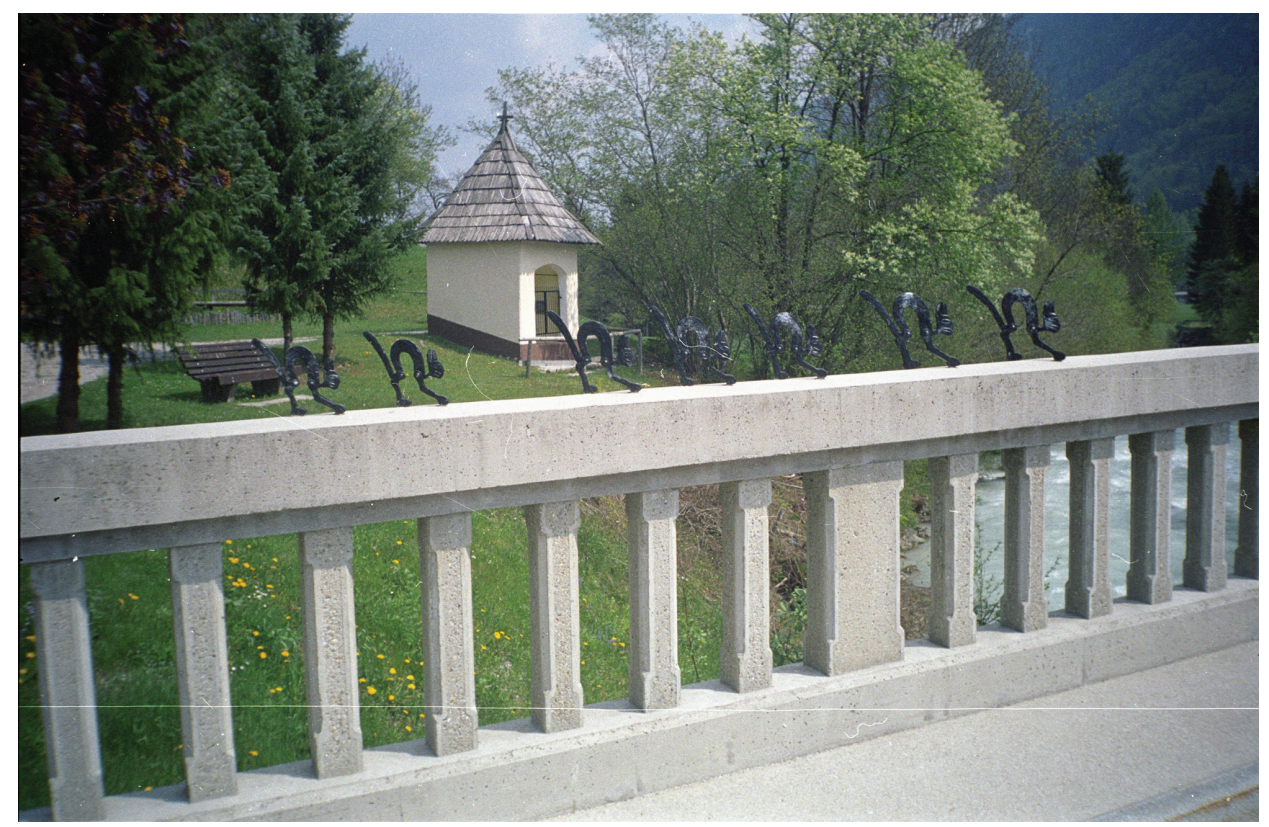

Figure 2. The fairy-tale trail of the Alpine area in Dovje near Mojstrana in Slovenia. Photograph by Monika Kropej 2006.

Children are guided through the mythical world of Velika Planina by the Wild Man (dovji mož). In Kranjska Gora, children and families can experience folktales about Pehta, Bedanc, and Kosobrin in Kekec Land (Source 7).

Professor of folklore studies, Mirjam Mencej, has, together with her students, collected tales, based on the local attractions of Kozjansko Regional Park, and published them in a booklet as a folktale guide (Mencej 2007).

Recently, a trail of narrative traditions related to the monuments of Ljubljana was also established (Kropej Telban 2019).

With their families, preschool children and children aged 6-9 years can enjoy adventures on the trail of krivopete (wild women with backward feet), where they can follow animal tracks and listen to the legends from the Trenta Valley (Source 8).

There are, of course, many more of these kinds of folktale trails in Slovenia, but we have presented only some as examples. 


\section{STRATEGIES FOR SAFEGUARDING NARRATIVE TRADITION IN PLACES}

To a large extent, folk narrative traditions connected to or located in places or spaces - space is more universal in scope, and place merely particular (Casey 1996: 13) - are offered through various presentations, public performances, tourist and cultural events, mass media, also through new ways of transmission and dissemination, mostly via the internet and other electronic media. This calls for new research approaches, methods, and strategies for the preservation of narrative cultural heritage.

Preservation strategies are structured by numerous national and international conventions and laws: national laws on safeguarding and preservation of cultural goods, the UNESCO Convention for the Safeguarding of the Intangible Cultural Heritage 2003 (Source 14), the UNESCO Atlas of the World's Languages in Danger (Source 11), the World Intellectual Property Organization (WIPO), the Faro 2005 Convention on the Value of Cultural Heritage for Society (Source 12), and the Yamato Declaration on Integrated Approaches for Safeguarding Tangible and Intangible Cultural Heritage (Source 13).

International safeguarding documents of governmental and non-governmental organizations share a common ground, emphasizing the importance of cultural heritage for the collective memory of humankind, which plays a vital role in the development of individuals and society. These documents also draw attention to the accessibility, irreplaceability, and authenticity of heritage (Delak Koželj 2013: 205). In this regard, new professional standards and sustainable development, which do not hamper but promote regional authenticity, must be taken into consideration. Contemporary standards and modern ethnological criteria for identifying "good" and "bad" strategies of preservation, promotion, and utilization of cultural heritage are mainly the following:

1. Ethnographic criterion. It emphasizes the phenomena that are typical for the local community and/or the area in question, be it still-existing phenomena with a long tradition, or extinct phenomena that reappear in a new form within a local tradition.

2. Environmental criterion. The phenomena we wish to preserve should be in harmony with the features of the environment (including the historical structure of the settlement or landscape), and they should support the positive development of the area and its environment.

3. Cultural-historical criterion. It follows the historical aspects of culture, and focuses on the traditional phenomena that have existed for generations, as well as on the newly formed phenomena derived from traditions, and can potentially promote its continuation and the emergence of a new 
tradition. The phenomena that are traditional in other regions, but have no historical roots in a given area, should be avoided.

4. Aesthetic criterion. The aesthetic function of the phenomena should be researched in view of the aesthetic criteria of the society and the times at which the phenomena appeared. The examples of aesthetically badly elaborated practices (e.g., traditional market with products from distant cultures, and presentation of aesthetically poorly manufactured products, i.e., kitsch) should be avoided.

5. Ethical criterion. Good practices should respect human rights, animal rights, dignity, ethics, hygiene, and similar factors.

6. Psychological criteria. The researched phenomena should pertain to the local, regional, or national identity, and should not oppose local values, consciousness or awareness (Ivančič Kutin \& Kropej Telban 2018).

In order to preserve narrative culture, various experts from different disciplines working within this field must endeavour to find common ground and to cooperate, for this is the only way to adequately influence cultural policy. The process of safeguarding includes defining, identifying, documenting, and presenting particular cultural traditions and their practitioners (Kirschenblatt-Gimblett 2006: 10). Through their work, ethnologists, culture, education, and tourism professionals, editors, radio and television journalists, and many others can draw the public's attention to the forgotten narrative culture and revive it.

The management and adaptation of the cultural heritage and its qualitative evaluation always reflect the relationship between the individuals or social groups who have the power to interpret it and those who create and transform it (Poljak Istenič 2013: 117-120; Slavec Gradišnik 2014: 10-11, 17). However, the latest ethnological research related to the role of cultural heritage within a wider cultural context shows that the revival of heritage often plays an important role in the preservation of local and other identities (e.g. Dolžan Eržen \& Slavec Gradišnik \& Valentinčič Furlan 2014). It connects people into groups and enhances the quality of life. In contrast, the popularization of cultural heritage can also cause the processes of "cultural economics" (KirschenblattGimblett 2006: 3) and can easily be exploited.

Experts also need to be careful not to fall into the trap of so-called "salvation ethnology", anthropology, and ethnography, when they collect, document, and prepare material from different kinds of sources (archive notes, published material, current field records, etc.); the points, methods, and means of approaching traditional culture, as well as the choice of elements that need to be salvaged (documented, described, but perhaps also truly preserved) changed over time 
and were differentiated, based on different theoretical starting points and areas of ethnological and folkloristic activities (Hameršak \& Pleše 2018: 137, 138).

In practice, we have to take care that the exploitation of folklore does not completely lose touch with tradition when it is used for commercial purposes, because, in that case, it becomes distorted and turns merely into a means of gaining profit (Kropej 2014: 254; Ivančič Kutin 2017: 50).

\section{RESEARCH AS A BASIS FOR A FOLKTALE TRAIL IN ISTRIA AND POHORJE}

In 2017, the European project under the heading Interreg Slovenia-Croatia: Living Magic (2017-2019) started. ${ }^{1}$ This project aimed to preserve narrative tradition in Pohorje (the Eastern Alps near Slovenska Bistrica in Slovenia) and in central Istria in Croatia. For this purpose, we prepared an appropriate methodology, which we based on theoretical findings and related practical experience, and we presented a programme for a better understanding, identification, and preservation of the intangible cultural heritage in the chosen areas. Our second objective was the preparation of a folktale trail through Slovenska Bistrica and its surrounding region as well as through central Istria. The accompanying products of the project are an illustrated book titled Živa coprnija Pohorja in Istre (Living Magic of Pohorje and Istria), ${ }^{2}$ a digital guide, puppet shows, and a promotional video. While preparing the folktale trails, we collected stories within the context of the chosen places, and later located them in the district. Ten locations in Bistriško Pohorje and central Istria were chosen, all of which are significant from both the cultural-historical and natural science points of view. For each marked station on the trail, we attempted to provide as many related legends as possible. The archives, older and newer publications, and much of the material that was collected during our survey fieldwork were analysed. An illustrated book was prepared (Cunta 2019), which was based on ten selected stories and which can also serve as a guidebook, because the spatial and cultural context of the stories has been defined and the selected folktales have been converted into literary form by Slovenian writer Dušan Šarotar. The material is also available in a web application, in the form of a socalled digital guide. Among all the recorded legendary characters, we chose the typical ones - rojenica (the Fate) from Pohorje and kresnik (a supernatural solar being or a person with magic abilities) from Istria. Individuals, groups, and families can enjoy the trail independently, every time visiting a different marked site or location. 


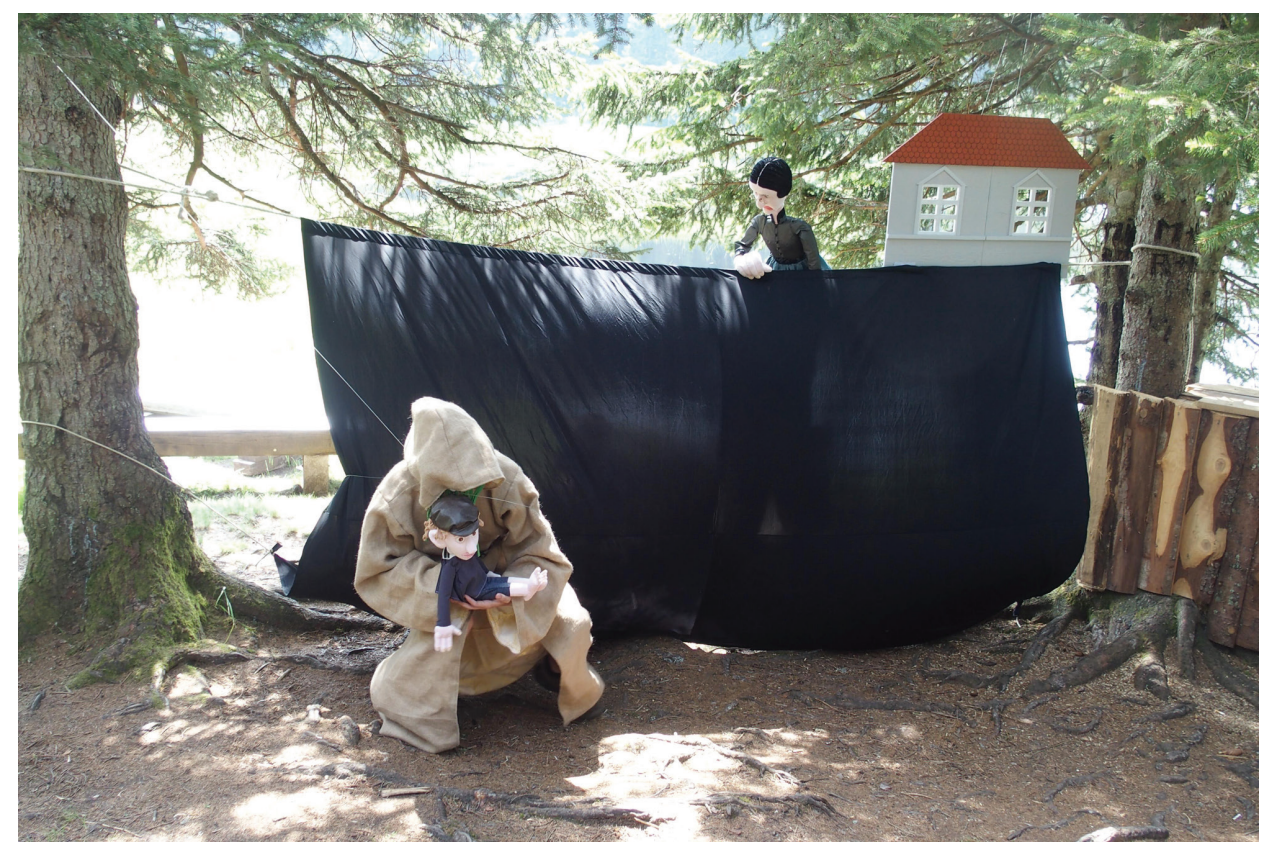

Figure 3. Folktale trail in Pohorje: Črno jezero (black lake) with a puppet show performed by the Koruzno zrno Society. Photograph by Stanka Drnovšek, 11 June 2019.

The folktale trails in Pohorje mostly include legends about people experiencing their natural environment and encountering the supernatural world. The legends tend to be somewhat frightening because apparitions often incite fear. The Pohorje trail starts in Slovenska Bistrica with its most prominent attraction, the Slovenska Bistrica Castle. Its previous owners were the counts of Attems, while today it is state-owned. The starting point in Istria is the settlement Gologorica in the municipality of Cerovo with its Roman Catholic Church of the Blessed Virgin Mary.

In our endeavour to ensure the preservation and presentation of the mythical heritage in Pohorje and Istria, we used approaches and methodologies that would bring the optimum results.

For this purpose, the following was necessary:

1. We analysed the sources, and researched the field (survey fieldwork, interviews with the locals, and workshops were carried out), and selected the original local narrative tradition regarding its level of quality and authenticity.

2. Folk tales were selected, which were integrated into the environment by means of appropriate practices and solutions, also by puppet and theatre shows and story-telling festivals. 
3. Products and activities were created in cooperation between researchers of different profiles and other experts, which would endeavour to ensure the preservation of intangible narrative heritage in Pohorje and Istria.

4. Scientific support in upgrading positive endeavours of the local people and individuals was offered.

5. Research institutes involved in this project offered assistance in achieving and presenting the final high-quality product.

This project aims to present the narrative heritage from a specific historical period by locating it in the modern world, in order to avoid repeating the stereotypical models connected to the past, or falling into the trap of artificial romanticism and noncritical modernization.

We wish to improve the recognition of narrative tradition by encouraging cooperation between the local communities and the groups that inherit the heritage through learning, identification, defining, performing, and transmission. We also popularized and promoted cultural heritage by educating people about the need for transferring knowledge and skills through seminars, workshops, as well as formal and non-formal education. The aim was to encourage the public to recognize and support the preservation of heritage. One of our main objectives was to reduce the risk of disappearance and devastation of the heritage, and its excessive commercialization.

The purpose of the overview and selection of narrative culture in Pohorje and Istria was to revitalize the narrative heritage, this way enriching the quality of the tourist and cultural services, and to broaden the horizons of spiritual creativity. In our endeavour to ensure the preservation of the narrative heritage in Pohorje and Istria, we attempted to weave the tradition into the present times while taking into consideration the quality of the results that are adapted to contemporary aesthetic and social values. We also had to reconsider the quality of the media by which the cultural heritage is transmitted.

\section{FOLKTALE TRAIL IN BOVEC: DIDACTIC APPROACH AND ITS INFLUENCE ON THE KNOWLEDGE OF THE LOCAL NARRATIVE TRADITION}

The storytelling legacy, beginning with local stories, is crucial for the improvement of the knowledge of local narrative tradition. Within the strategies for improving and increasing the inter- and intracultural ${ }^{3}$ dialogue, it serves as the foundation for the strengthening of the cultural consciousness and the cultural capital, which in turn serves as the basis for a strong sense of individual, national, and global identity (Blažić \& Žbogar 2018: 229). 
Because of the power of the empirical experience, thematic trails can also be welcome as a support mechanism for the instruction and teaching of folk narratives in schools. The didactic method, the so-called flipped learning / flipped classroom, where learning takes place by viewing or listening to recordings outside the school, while classes are intended for research, collaborative work, discussion, and similar activities (Žbogar 2019: 36, 37), can be very effective in teaching the local narrative tradition.

In the Bovec region in the western part of Slovenia, on the border between Slovenia and Italy, in recent decades people have witnessed a growing interest and effort for the greater recognition of the local storytelling tradition. This interest has roots in tourism and culture but has consequently affected primary school pupils as well. Thematic trails, audio and video presentations of storytellers and their stories in the Bovec museum called Stergulčeva hiša (Stergulc House) for its permanent collection, performances, projects, and similar, help to improve the knowledge of local narrative tradition.

In addition, an ethnological and historical trail that is equipped with information boards has also existed in Bovec for the last ten years. On the same trail, in cooperation with folklorists in 2013, the storytelling thematic route called "In the footsteps of the narrative tradition of Bovec" was also established. While strolling around Bovec and its surroundings, the visitors (individually or in a group) can stop at 14 points and, with the support of a GPS device, can listen to recordings of the narratives (Ivančič Kutin 2013). All stories are contextually related to the place in which the visitor is located. Slovenian versions of these stories are narrated in the local dialect, as it forms an essential part of local identity. The stories that were chosen are less known; they were in danger of falling into oblivion.

In the same year (2013), survey research was conducted among schoolchildren from the 6 th to the 9 th forms (ages 11 to 15), 74 pupils in total, who were asked to self-assess the degree of their familiarity with nine selected local narratives (four of the selected stories are also part of the folktale trail), the choice of answers being as follows:

1) I know it and I am able to narrate it;

2) I know it and I can make a short summary;

3) I have heard it but I cannot say what it is about;

4) I have never heard it.

The first two answers show active knowledge, the third one passive knowledge, and the fourth answer shows complete ignorance. The results reveal that pupils' familiarity with local folktales is quite poor. In that hope that this thematic route might improve the knowledge of the local folklore tradition, the Bovec elementary school was invited to integrate the thematic trail into the school 


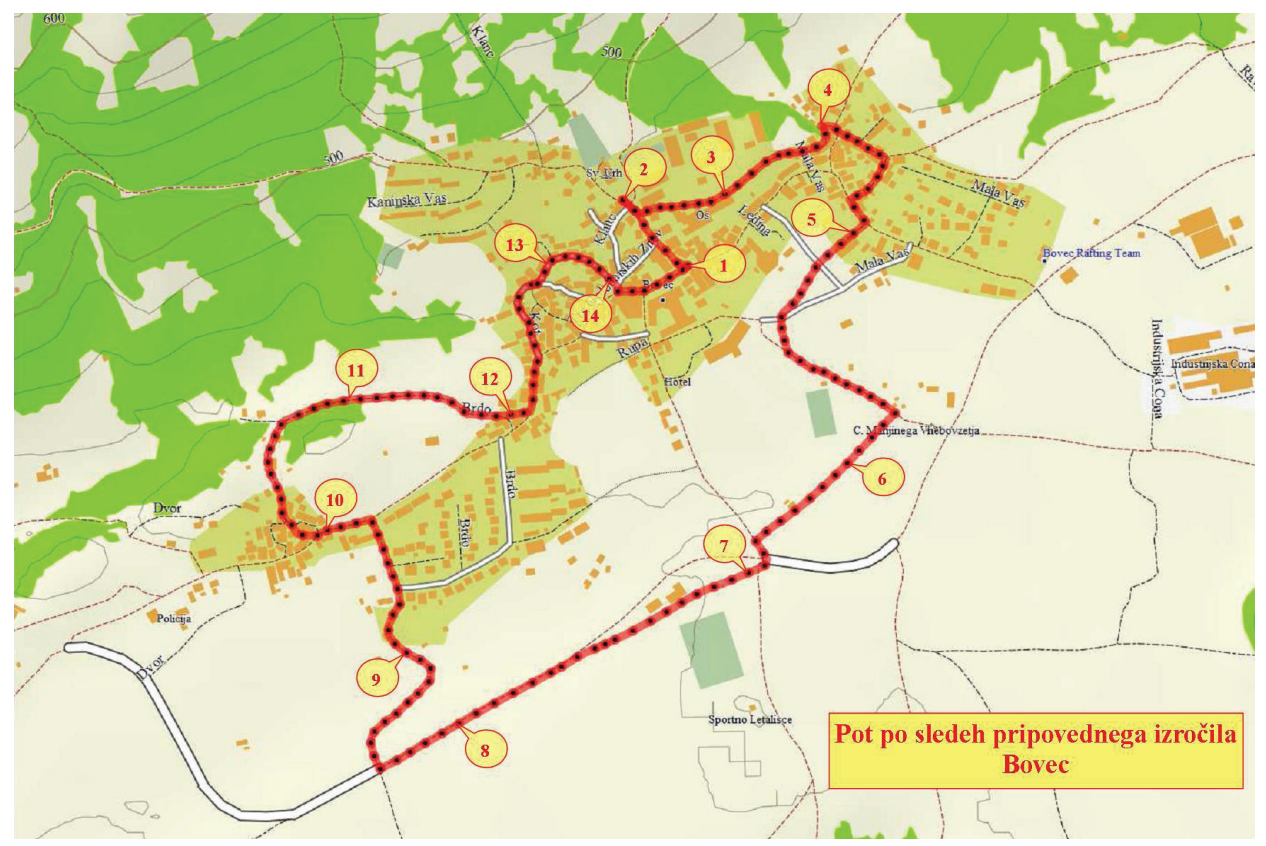

Figure 4. Map of the thematic trail following the narrative tradition of Bovec from the brochure Podeželski elektronski vodič (Rural Electronic Guide) (2013).

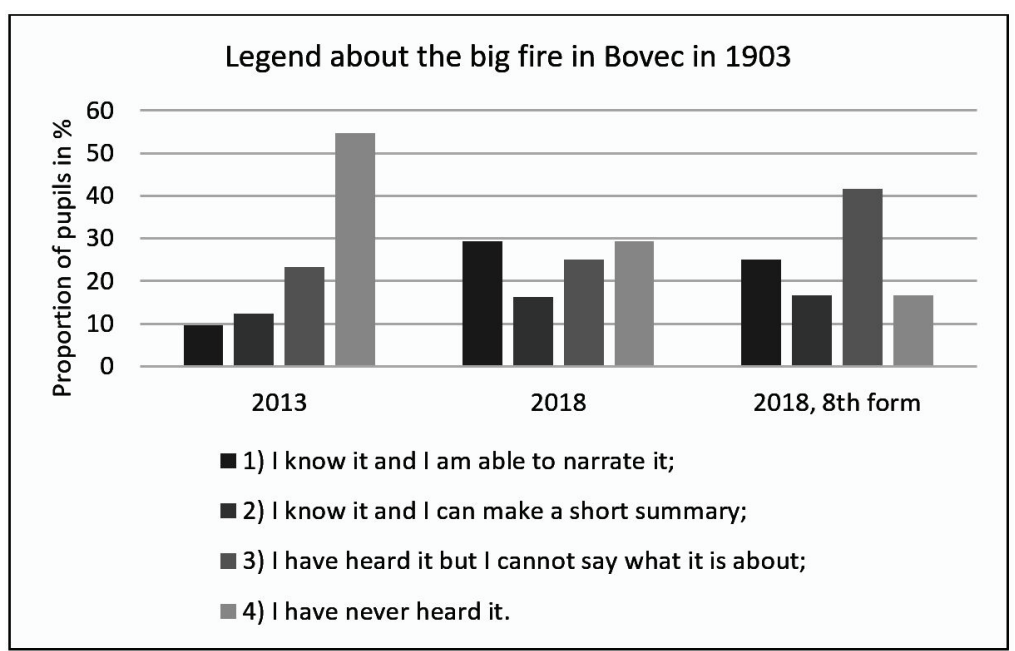

Figure 5. Self-assessment of familiarity with the local stories about the big fire in Bovec in 1903 in a survey conducted in 2013 and in 2018. A special focus is on group 2018, the 8th form, which was guided along the thematic trail. 
curriculum and in this manner to enable schoolchildren to learn it well. After some years, in 2018, the same survey research was repeated in a new generation of pupils from the 6 th to the 9 th forms, 68 in total; the knowledge had noticeably increased, above all among the pupils who were guided along the thematic trail or via legend-tripping ${ }^{4}$ within the framework of school activities (group 2018; 8th form). ${ }^{5}$ For example, as can be seen in Figure 5, the proportion of pupils who have active knowledge of the historical "Legend about the big fire in Bovec in 1903" increased (see the first two columns) and the proportion of pupils who had never heard of this legend (last column) declined significantly (55 percent in 2013, 29 percent in 2018, and 17 percent in the observed group) (Ivančič Kutin 2019).

\section{CONCLUSION}

Narrative folklore is changing, even faster than previously, due to the rapid advancement of technology, electronics, and virtual communication. Furthermore, heritage is bound to change, as Valdimar Hafstein has put it: "Don't let all the talk about preservation fool you: all heritage is change" (Hafstein 2007: 75). At the same time also completely new forms of narrative culture are arising, which are related to new ways of transmission and dissemination, mostly via festivals, storytelling events, and through the creation of "legendary landscapes".

Narrative tradition may be considered a resource that can serve as a basis for diverse activities aimed at preserving the cultural identity and cultural heritage of the existing social groups in a given local environment. Traditional narrative genres and contents today no longer depend solely on oral transmission, given the existence of multiple media - from print and television to social networks - which in turn also allow for internationalization and globalization. In this context, the function of narrative tradition has changed and can also be part of the social or cultural development of the region. It can be either part of sustainable tourism or, if not well thought out, of the heritage industry.

As can be seen from the examples discussed in this article, the preservation of the narrative heritage is based on the fact that the concept of heritage refers to the past, although it is deeply rooted in the present, and selectively used for contemporary purposes and needs. When selecting narrative units which are always removed from their original context, it is important to focus on the criteria and strategies with which we can thoughtfully incorporate narrative folklore or local legends - with the aid of experts - into the local cultural and tourist environment. It is necessary to prevent the danger that the local stories would be translated and re-interpreted within the framework of commercial guidelines and applied to produce some "legendary fiction-land" as Cristina Bacchilega 
has noted in the case of Hawaii, where folklore genres were applied and staged for the Western visitors (Bacchilega 2007). In contrast, the so-called intangible cultural heritage can lead to rivalries between local communities (Noyes 2006: 41; Tauschek 2010), which is also one of the problems of heritage preservation.

Because of the power of the empiric effect, thematic trails can also be effective as a support mechanism when teaching folk narratives in schools, and for improving sustainable tourism. However, they can soon become a part of the heritage industry which today is a modern economic factor in societies, but unfortunately often not well conceived.

Nevertheless, many criteria must be considered as parts of the process for the presentation of local legends in situ. It is true that elements of cultural heritage are no longer part of the active processes of tradition (Kockel 2007: 29), but since the transmission of the tradition causes the creation of new forms, the revitalization of tradition and preservation of heritage can often be the mainspring of local tourism and culture. Heritage and tradition are products of modernization processes; outside of this context, they seem non-existent. Heritage creates so-called present pasts, which always reflect the views of the past from the viewpoint of today and cannot avoid the claws of ideology or political interests. In recent times, this is clearly seen in emphasizing the important aspect of narrative heritage for cultural identity, as well as economic and social growth.

Even though the presentation of place-lore in situ can be problematic, it cannot be overlooked that genius loci is overcoming boundaries of time and gives a certain character to places (Kropej 2003: 78). However, regardless of different ways in which such heritage is preserved and presented, it has become clear that the permanent factors in its preservation are the people and the places; the outside factors in this process, in contrast, are more or less changeable.

\section{ACKNOWLEDGEMENTS}

This research was partly supported by the European Interreg Slovenian-Croatian project, Living Magic - Živa coprnija - Živa štrigarija, 2017-2019, financed by the European Regional Development Fund and partly by the Slovenian Research Agency, the research programme "Cultural Spaces and Practices: Ethnology and Folklore Studies, 1 January 2015 - 31 December 2021” (P6-0088).

\section{NOTES}

${ }^{1}$ For more detailed description see Source 9. 
${ }^{2}$ Cunta, Miljana (ed.). Živa coprnija Pohorja in Istre. Izleti po poteh pripovednega izročila. Ljubljana: Beletrina 2019 (also published in the English and Croatian languages).

3 The importance, methods, and goals of cultural and intercultural connections in the teaching of literature were discussed at the Congress of the Slavic Society of Slovenia (see Žele 2015).

4 Though this term can have a negative connotation (Kinsella 2011), it is used in this connection in a positive sense for the legend trails.

5 Full results of the analysis are published in Ivančič Kutin 2019.

\section{REFERENCES}

Bacchilega, Cristina 2007. Legendary Hawai'i and the Politics of Place: Tradition, Translation, and Tourism. Philadelphia: University of Pennsylvania Press.

Bausinger, Hermann 1969. Folklorismus in Europa: Eine Umfrage. Zeitschrift für Volkskunde, Vol. 65, No. 1, pp. 1-8.

Bendix, Regina 1997. In Search of Authenticy: The Formation of Folklore Studies. Madison: The University of Wisconsin Press.

Bendix, Regina 2002. Capitalizing on Memories Past, Present, and Future: Observations on the Intertwining of Tourism and Narration. Anthropological Theory, Vol. 2, No. 4, pp. 469-487. http://dx.doi.org/10.1177/14634990260620567.

Bird, S. Elizabeth 2002. It Makes Sense to Us: Cultural Identity in Local Legends of Place. Journal of Contemporary Ethnography, Vol. 31, No. 5, pp. 519-547. http:// dx.doi.org/10.1177/089124102236541.

Blažić, Milena Mileva \& Žbogar, Alenka 2018. Pravljice v slovenskem vzgojnoizobraževalnem sistemu od vrtca do srednje šole. [Fairy Tales in the Slovenian Educational System from Kindergarten to High School.] In: Andreja Žele \& Matej Šekli (eds.) Slovenistika in slavistika $v$ zamejstvu - Videm. Ljubljana: Zveza društev Slavistično društvo Slovenije, pp. 221-231. Available at https://en.calameo. com/read/000889460692ab68eba44, last accessed on 9 September 2020.

Bošković-Stulli, Maja 1971. O folklorizmu. [About Folklorism.] Zbornik za narodni život I običaje, Vol. 45, pp. 165-186. Available at https://dizbi.hazu.hr/ $\mathrm{a} /$ ?pr=toc\&id=10667, last accessed on 9 September 2020.

Casey, Edward S. 1996. How to Get from Space to Place in a Fairly Short Stretch of Time: Phenomenological Prolegomena. In: Steven Feld \& Keith H. Basso (eds.) Senses of Place. Santa Fe, New Mexico: School of American Research Press, pp. 13-52.

Cashman, Ray 2011 [2008]. Storytelling on the Northern Irish Border: Characters and Community. Bloomington \& Indianapolis: Indiana University Press.

Cerar Drašler, Irena 2004. Pravljične poti Slovenije. Družinski izletniški vodnik. [Folktale Routes of Slovenia: Family Excursion Guide.] Ljubljana: Sidarta.

Cerar, Irena 2015. Kamniške pravljične poti: družinski izletniški vodnik. [Folktale Routes of Kamnik: Family Excursion Guide.] Ljubljana: Sidarta.

Chittenden, Tara 2011. Opening the Door to Old Town Key West: Physical Thresholds in the Storied Narrative of the Conch Train Tour. Storytelling, Self, Society, Vol. 7, No. 3, pp. 169-187. 
Cunta, Miljana (ed.) 2019. Living Magic of Pohorje and Istria: Trips along the Paths of Lore. Ljubljana: Beletrina.

Delak Koželj, Zvezda 2013. Etnolog in celostno ohranjanje kulturne dediščine. [Ethnologist and the Integral Approach to Cultural Heritage Protection.] Traditiones, Vol. 42, No. 1, pp. 201-220. https://doi.org/10.3986/Traditio2013420112.

Dolgan, Marjan \& Fridl, Jerneja \& Volk, Manca 2014. Literarni atlas Ljubljane. [Literary Atlas of Ljubljana.] Ljubljana: ZRC SAZU.

Dolžan Eržen, Tatjana \& Slavec Gradišnik, Ingrid \& Valentinčič Furlan, Nadja (eds.) 2014. Interpretacije dediščine. [On Heritage Interpretation.] Ljubljana: Slovensko etnološko društvo.

Ellis, Bill 1996. Legend Trip. In: Jan Harold Brunvand (ed.) American Folklore: An Encyclopedia. New York \& London: Garland, pp. 920-922. Available at http://1. droppdf.com/files/IlMsW/encyclopedia-of-american-folklore.pdf, last accessed on 9 September 2020.

Frlic, Špela 2016. Sodobno pripovedovanje folklornih pripovedi v slovenskem prostoru. [Contemporary Storytelling of Folklore Narratives in the Slovenian Space.] Diss. (MA Thesis). University of Ljubljana.

Goldstein, Diane E. \& Gryder, Sylvia Ann \& Banks Thomas, Jeannie 2007. Haunting Experiences: Ghosts in Contemporary Folklore. Logan, Utah: Utah State University.

Hafstein, Valdimar Tr. 2007. Claiming Culture: Intangible Heritage Inc., Folklore®, Traditional Knowledge ${ }^{\mathrm{TM}}$. In: Dorothee Hemme \& Markus Tauschek \& Regina Bendix (eds.) Prädikat "HERITAGE": Wertschöpfungen aus kulturellen Ressourcen. Berlin: LIT Verlag, pp. 75-100.

Hameršak, Marijana \& Pleše, Iva 2018. Heritage on Demand: UNESCO Intangible Cultural Heritage Initiative in Croatian Context. Folklore: Electronic Journal of Folklore, Vol. 74, pp. 129-152. https://doi.org/10.7592/FEJF2018.74.croatia.

Ivančič Kutin, Barbara 2010. Folklorna pripoved v urbanem okolju, v javnem prostoru: Pripovedovalski dogodki v slovenski prestolnici. [Folklore Narrative in the Urban Environment, in the Public Space: Storytelling Events in the Slovenian Capital City.] In: Irena Novak Popov (ed.) Vloge središča: Konvergenca regij in kultur. Ljubljana: Slovenski slavistični kongres, pp. 200-209. Available at https://zdsds. si/tiskovina/597/, last accessed on 9 September 2020.

Ivančič Kutin, Barbara 2013. Zvočni vodnik po tematski poti: Po sledeh pripovednega izročila Bovca. Zvočni CD. [Audio Guide for a Thematic Route: Following the Trail of the Narrative Tradition of Bovec. Audio CD.] Ljubljana: AVL ZRC SAZU.

Ivančič Kutin, Barbara 2017. Transformacije (slovstvene) folklore v sodobni kulturi: Krivopete v Zgornjem Posočju in Benečiji. [Transformations of (Verbal) Folklore in Contemporary Culture: Krivopete in the Upper Soča Valley and in Venetia.] Traditiones, Vol. 46, No. 1-2, pp. 37-54. https://doi.org/10.3986/Traditio2017460102.

Ivančič Kutin, Barbara 2019. Tematske poti in drugi izkustveni didaktični pristopi pri obravnavi folklornih besedil v osnovni šoli. [Thematic Trails and Other Experiential Approaches to Teaching Verbal Folklore in Primary School.] Jezik in slovstvo, Vol. 64, No. 2, pp. 95-108.

Ivančič Kutin, Barbara \& Kropej Telban, Monika 2018. Ohranjanje nesnovne kulturne dediščine z lokalnimi pripovedmi v prostoru. [Preservation of Intangible Cultural Heritage through Local Legends of Place.] Traditiones, Vol. 47, No. 3, pp. 103-115. https://doi.org/10.3986/Traditio2018470307. 
Ivančič Kutin, Barbara \& Marjanić, Suzana 2015. "Poslušajte, dragi ljudje, najboljša fabrika je turizem!”: Portret in zgodbe Jožeta Brileja iz Podčetrtka. ["Listen, Dear People, the Best Factory Is Tourism!": Portrait of Jože Brile from Podčetrtek and His Narratives.] Glasnik Slovenskega etnološkega društva, Vol. 55, No. 3-4, pp. 153-155. Available at https://www.sed-drustvo.si/publikacije/glasnikslovenskega-etnoloskega-drustva/glasniki/glasnik-slovenskega-etnoloskegadrustva-55-34-2015, last accessed on 9 September 2020.

Kinsella, Michael 2011. Legend-Tripping Online: Supernatural Folklore and the Search for Ong's Hat. Jackson, MS: The University Press of Mississippi.

Kirschenblatt-Gimblett, Barbara 2006. World Heritage and Cultural Economics. In: Ivan Karp \& Corinne A. Kratz \& Lynn Szwaja \& Tomás Ybarra-Frausto (eds.) Museum Frictions: Public Cultures / Global Transformations. Durham \& London: Duke University Press, pp. 161-202.

Klaus, Simona 2014. Pa vse, kar sem hotu, so ble dobre vile: Folklora v oglasih med letoma 1980 in 2011 v Sloveniji. [Folklore in Advertisement in Slovenia between 1980 and 2011.] Ljubljana: Znanstvena založba Filozofske fakultete.

Kockel, Ullrich 2007. Reflexive Traditions and Heritage Production. In: Ullrich Kockel \& Máiréad Nic Craith (eds.) Cultural Heritage as Reflexive Traditions. New York \& Basingstoke: Palgrave Macmillan, pp. 19-33.

Kõiva, Mare (ed.) 2009. Media \& Folklore: Contemporary Folklore 4. Tartu: ELM Scholarly Press. Available at http://www.folklore.ee/rl/pubte/ee/cf/cf4/, last accessed on 9 September 2020.

Köstlin, Konrad 1970. Folklorismus und Ben-Akiba. Rheinisches Jahrbuch für Volkskunde, Vol. 20, pp. 234-256.

Krawczyk-Wasilewska, Violetta \& Meder, Theo \& Ross, Andy (eds.) 2012. Shaping Virtual Lives: Online Identities, Representations and Conducts. Lodž: Widawnictwo Universytetu Łodžkiego.

Kropej, Monika 2003. Po sledeh ljudskega pripovedništva v Rožu. [Following the Traces of Folk Narrative in Rosental.] Traditiones, Vol. 32, No. 1, pp. 57-81.

Kropej, Monika 2007. Folk Narrative in the Era of Electronic Media: A Case Study in Slovenia. Fabula, Vol. 48, No. 1-2, pp. 1-15. https://doi.org/10.1515/FABL.2007.002.

Kropej, Monika 2014. Narrative Tradition about King Matthias in the Process of Transformation. Slovenský národopis / Slovak Ethnology, Vol. 62, No. 2, pp. 244-258. Available at https://uesa.sav.sk/files/etno2-text-web-27-6.pdf, last accessed on 9 September 2020.

Kropej Telban, Monika 2019. Pripovedna pot po Ljubljani: Slovstveno izročilo kot del ogleda mesta. [A Storytelling Tour of Ljubljana: Narrative Heritage as Part of Sightseeing.] Jezik in slovstvo, Vol. 64, No. 2, pp. 79-94. Available at https://www. jezikinslovstvo.com/stevilka.php?SID=164, last accessed on 9 September 2020.

Kunčič, Mirko 1940. Triglavske pravljice 1. [Triglav Fairy Tales 1.] Ljubljana: Učiteljska tiskarna.

Kunčič, Mirko 1944. Triglavske pravljice 2, 3. [Triglav Fairy Tales 2, 3.] Ljubljana: Učiteljska tiskarna.

March, Richard 2013. The Tamburitza Tradition: From the Balkan to the American Midwest. Madison, Wisconsin: The University of Wisconsin Press. 
Mathisen, Stein R. 1993. Folklore and Cultural Identity. In: Pertti J. Anttonen \& Reimund Kvideland (eds.) Nordic Frontiers: Recent Issues in the Study of Modern Traditional Culture in the Nordic Countries. Turku: Nordic Institute of Folklore, pp. 35-47.

Mencej, Mirjam 2007. Po poteh zgodb. [Following the Trails of the Tales.] Podsreda: Kozjanski park.

Moser, Hans 1962. Vom Folklorismus in unserer Zeit. Zeitschrift für Volkskunde, Vol. 58, pp. 177-209. Available at http://www.digi-hub.de/viewer/image/DE-11001929032/527/, last accessed on 9 September 2020.

Noyes, Dorothy 2006. The Judgement of Solomon: Global Protections for Tradition and the Problem of Community Ownership. Cultural Analysis, Vol. 5, pp. 27-56. Available at https://www.ocf.berkeley.edu/ culturalanalysis/volume5/pdf/vol5. pdf, last accessed on 9 September 2020.

Pöge-Alder, Kathrin 2010. Strategien des öffentlichen Erzählens Heute. In: Ulrich Marzolph (ed.) Strategien des populären Erzählens. Göttingen: Universität Göttingen, pp. 107-125.

Poljak Istenič, Saša 2011. Texts and Contexts of Folklorism. Traditiones, Vol. 40, No. 3, pp. 51-73. https://doi.org/10.3986/Traditio2011400304.

Poljak Istenič, Saša 2013. Tradicija v sodobnosti: Janče - zeleni prag Ljubljane. [Tradition in the Contemporary World: Janče - the Green Threshold of Ljubljana.] Ljubljana: Založba ZRC.

Rihtman Auguštin, Dunja 1978. Folklor, folklorizam i suvremena publika. [Folklore, Folklorism and Contemporary Audience.] Etnološka tribina: Godišnjak Hrvatskog etnološkog društva, Vol. 7-8, No. 1, pp. 21-28. Available at https://hrcak.srce.hr/ index.php?show=clanak\&id_clanak_jezik=118957, last accessed on 18 December 2020.

Slavec Gradišnik, Ingrid 2014. V objemu dediščin. [In the Embrace of Heritage.] In: Tatjana Dolžan Eržen \& Ingrid Slavec Gradišnik \& Nadja Valentinčič Furlan (eds.) Interpretacije dediščine. Ljubljana: Slovensko etnološko društvo, pp. 8-24.

Stokowski, Marek 2013. Legends and Tales of Malbork Castle. Hamburg: TopSpot Guide.

Šmidchens, Guntis 1999. Folklorism Revisited. Journal of Folklore Research, Vol. 36, No. 1, pp. 51-70. DOI: 10.2307/3814813.

Žbogar, Alenka 2019. Slovensko ljudsko slovstvo in antična književnost pri pouku književnosti. [Slovenian Folk Heritage and Ancient Literary Texts in Literature Classes.] Jezik in slovstvo, Vol. 64, No. 2, pp. 31-40. Available at https://www. jezikinslovstvo.com/stevilka.php?SID=164, last accessed on 10 September 2020.

Žele, Andreja (ed.) 2015. Bilten ob štiridesetletnici zveze pokrajinskih slavističnih društev (konferenčni zbornik). [Bulletin for the 40th Anniversary of the Association of Provincial Slavic Societies (Conference Proceedings).] Ljubljana: Zveza društev Slavistično društvo Slovenije. Available at https://en.calameo.com/ $\mathrm{read} / 00088946017927 \mathrm{e} 50 \mathrm{af51}$, last accessed on 10 September 2020.

Tauschek, Markus 2010. Cultural Property as Strategy: The Carnival of Binche, the Creation of Cultural Heritage and Cultural Property. Ethnologia Europaea, Vol. 39, No. 2, pp. 67-80.

Valk, Ülo \& Sävborg, Daniel (eds.) 2018. Storied and Supernatural Places: Studies in Spatial and Social Dimensions of Folklore and Sagas. Studia Fennica Folkloristica 23. Helsinki: Finnish Literature Society. 


\section{ONLINE SOURCES}

Source 1: https://www.scottishstorytellingcentre.com/, last accessed on 3 September 2020.

Source 2: https://www.visitestonia.com/en/lottemaa-theme-park-the-largest-familytheme-park-in-estonia, last accessed on 3 September 2020.

Source 3: http://carovnica.si/, last accessed on 8 September 2020.

Source 4: http://www.pravljicedanes.si/; https://pripovedovalskifestival.si/, both last accessed on 3 September 2020.

Source 5: https://www.outdooractive.com/de/wanderung/carnica-region rosental/ familienwanderung-zur-maerchenwiese/1524442/,_last accessed on 3 September 2020.

Source 6: https://www.bohinj.si/dozivetja/zlatorogova-pravljicna-pot/, last accessed on 8 September 2020.

Source 7: https://www.kranjska-gora.si/sl/aktivnosti/druzinske-pocitnice/pravljicnedezele/kekceva-dezela, last accessed on 8 September 2020.

Source 8: https://www.tnp.si/sl/obiscite/nepozabna-dozivetja/programi-za-sole/, last accessed on 8 September 2020.

Source 9: https://ric-sb.si/ziva-coprnija, last accessed on 8 September 2020.

Source 10: http://www.mojstrana.com/sl/lokalna-ponudba/gledalisce-v-naravi/rajze-popoteh-triglavskih-pravljic/, last accessed on 8 September 2020.

Source 11: http://unesdoc.unesco.org/images/0019/001924/192416e.pdf, last accessed on 8 September 2020.

Source 12: https://www.coe.int/en/web/culture-and-heritage/faro-convention, last accessed on 8 September 2020.

Source 13: https://australia.icomos.org/wp-content/uploads/Yamato_Declaration.pdf, last accessed on 8 September 2020.

Source 14: http://portal.unesco.org/en/ev.php-URL_ID=17716\&URL_DO=DO_ TOPIC\&URL_SECTION=201.html, last accessed on 8 September 2020.

Monika Kropej Telban is a Research Advisor (PhD) at the Institute of Slovenian Ethnology at the Scientific Research Centre of the Slovenian Academy of Sciences and Arts in Ljubljana. She studies folk narrative tradition, mostly folktales and fairy tales, and focuses on the processes of modification of folklore genres and folk beliefs and on contemporary narrative culture.

monika@zrc-sazu.si

Barbara Ivančič Kutin is Research Fellow $(\mathrm{PhD})$ at the Institute of Slovenian Ethnology at the Scientific Research Centre of the Slovenian Academy of Sciences and Arts, Ljubljana, Slovenia. Her research interests include folk narratives in terms of their performance and language. Her approach encompasses folkloristic, ethnological, and dialectological methods. Her research is mainly based on her own fieldwork.

b.ivancic@zrc-sazu.si 